\title{
Family Socioeconomic Status and Deviant Behaviour Among Secondary School Students in Homabay County, Kenya
}

\author{
Dorothy Anyango Aute, Moses Wesang'ula Poipoi, Okaya Edward Khasakhala \\ Department of Psychology, Masinde Muliro University of Science and Technology, Kakamega, Kenya \\ Email address: \\ auteagai@yahoo.com (D. A. Aute),Wpoipoi@mmust.ca.ke (M. W. Poipoi), eokaya@mmust.ac.ke (O. E. Khasakhala)
}

\section{To cite this article:}

Dorothy Anyango Aute, Moses Wesang'ula Poipoi, Okaya Edward Khasakhala. Family Socioeconomic Status and Deviant Behaviour Among Secondary School Students in Homabay County, Kenya. Science Journal of Education. Vol. 8, No. 1, 2020 , pp. 14-21.

doi: $10.11648 /$ j.sjedu.20200801.13

Received: January 13, 2020; Accepted: February 4, 2020; Published: February 25, 2020

\begin{abstract}
Every society has its norms that govern the behaviour of its members thus any behaviour contrary to the norms of the society is considered deviance. There are a number of factors that are associated with deviance and one of them is poverty. The socioeconomic status of a family affects virtually all the aspects of life in that family including physical, emotional, mental and the parental environment. It further contributes to the behaviour of both the parents and the children in the family. Irrespective of the fact that Homabay County is situated along the lake, majority of the residents languish in abject poverty and consequently there is rampant deviance among the secondary school students in Homabay County. Deviance has devastating effects which include destruction of learning facilities, early pregnancies, arrests and even deaths. The objective of the study was to evaluate the relationship between family socioeconomic status and deviant behaviour among secondary school students inHomabay County. The study adopted Structural Strain Theory by Robert Merton which provided a conceptual link between family socioeconomic status and deviant behaviour. The study adopted a correlational survey design and the target population included form two students from all the secondary schools in Homabay County, heads of guidance and counseling department, Deputy Principals, Principals and selected members of parents association. Out of the population of 20,160 students a representative sample of 512 students was randomly sampled. Principals, Deputies, PA representatives and HODs were purposively sampled. Instruments for data collection included questionnaires administered to measure family socioeconomic status and deviant behaviour, structured and unstructured interview schedules, focus group discussions and analysis of documents from the sampled schools. Instruments were then piloted. The validity of these instruments was ascertained through expert judgment and piloting while the reliability of the instruments was tested using the Split half method and the level of confidence was $\alpha \leq 0.05$. Data was analyzed both quantitatively and qualitatively. The findings revealed significant negative correlation between SES and deviant behaviour $(\mathrm{r}=-0.644, \mathrm{p}<0.05)$.
\end{abstract}

Keywords: Family Socioeconomic Status, Deviant Behaviour, Secondary School Students

\section{Introduction}

All parents would love to be the best for their children by being fully responsive to the needs of their children, being there for the children emotionally and physically and consequently developing a secure attachment with their children. All these would ensure that the children grow up to be responsible and independent people who are able to coexist peacefully with others in the community. However, it becomes a big challenge when a parent is not able to provide for the children as expected of him.

Family socioeconomic status refers to parents' literacy level, house hold income, the presence of both parents and whether the parent is employed or not Nezhad, Mehr \& Rahmati [18]. This implies that a higher socioeconomic status would translate to higher house hold income, a higher level of parent education, full time employment and a two parent house hold and the opposite would be true for low socioeconomic status. A person is considered poor when his measured standard of living in terms of income or 
expenditure is below the poverty line Uyang, Abul \& Bassey [29]. The level of poverty in the country has escalated so much that the poor families strain to get the very basic needs. These economic constraints have devastating effects that spill over to the parent-child relationship and consequently affect the behaviour of the children. This study assumed that the students from low socioeconomic status families are likely to become deviants and consequently exhibit poor academic performance.

Kasundu, Mutiso, Chebet, Chesire and Mwirigi [11] opined that deviant behaviour is any antisocial behaviour which by nature is not acknowledged by the society. It is a behaviour that contradicts the ideals of the society. In Kenya, cases of deviant behaviour have been rampant ranging from students' unrest, drug use, bunking school, teenage pregnancies and teenage marriages and other forms of violence.

\subsection{Theoretical Framework}

The Structural Strain Theory by Robert Merton [15] states that social structures within society may pile pressure on citizens to commit crime.

Every child who goes to school has a goal, which can either be personal or communal. In most cases these goals are directed towards achieving economic success. By going to school, they perceive education as a legitimate means of achieving their goals which are also in away influenced by their culture. Thus success in school or education would imply economic success, while failure in education/school would imply economic failure. Most students especially those who are socially underprivileged find difficulty sustaining themselves in schools because of their socioeconomic status.

According to Merton [15], when faced with strain, people have five ways to adapt. The first group consists of those who conform to society's norms and values despite their strain. They believe they should work to make money and continue to be good, law abiding citizens. This adaptation is referred to as conformity. There are those who when faced with strain they still pursue economic stability but they invent new strategies of achieving it, some of which may be illegal. This adaptation is referred to as innovation. Ritualism is the kind of adaptation of the pessimists who continue to work without much hope of improving their lives. This adaptation is a logical reaction to the strain poor people experience. Retreatism is the adaptation of those who reject both the cultural goals and the means to obtain them then find a means to escape it for example, by becoming hobos or drug addicts. Finally, rebellion is the adaptation that involves rejecting the cultural goals and the means then strive to create a new society with a new value system. Such individuals may include the radicals and the revolutionists Giddens \& Sutton [9].

Deviant behaviour among adolescents is experienced globally. In America adolescents increasingly get involved in deviant activities thus posing a great challenge to the country as a whole Parks [24]. Harrison [10] also reported that most of the violent crimes in Florida in the year 2011 were committed by the youths. In Ethiopia, youths highly engage in risky sexual behaviour thus making them the most vulnerable to sexual health problems Tadesse, Mitikie, Yemane, Amenu \& Tesfaye [27]. In Kenya, deviance among secondary school students is exhibited across all the schools in the country. In an attempt to mitigate deviance in secondary schools the government of Kenya has had several task forces investigating the possible causes of deviance in the Kenyan schools, the latest one being the 2017 task force (MOE, 2017) which also acknowledged the contribution of the family to the behavior of their children. A major flaw in most of these reports is that despite acknowledging the fact that the family has a role to play if deviance is to be arrested in our schools, in their recommendations they are quiet about family socioeconomic status. A cross sectional study carried out by The Kenya National Crime Research Centre [28] from 16 counties that had experienced incidences of student unrest and arsons also ranked parents/guardians and family third in the category of individuals and institutions contributing to unrest in schools. This further necessitates the need for research on the role of parents and the family as a whole in curbing deviance in our schools.

For a long time, people assumed that the only way to restrain deviance is by corporal punishment but this has failed since it only leads to a lot of acting out among our students. According to Changalawa, Ndurumo, Barasa and Poipoi [4], dependence on corporal punishment to control behavior results to poor adjustment and deviance and inhibits development of internal control. It is also illogical to punish a hungry student who gets involved in deviance in order to find food and other basic needs.

The study was carried out in Homa Bay County which is one of the counties in Nyanza region situated along Lake Victoria. Between the year 2018 and mid 2019 almost 100 cases of deviance were reported, which led to destruction of property, physical injury, school dropout and finally poor academic performance in the affected schools (Homa bay County Education Officer, 2019).

\subsection{Area of Study}

Homa bay County shares its borders with Migori, Kisii and Kisumu County. There are a total of eight sub counties within the county and they include; Mbita, Ndhiwa, Homabay Town, Rangwe, Rachuonyo South, Rachuonyo north, Kabondo Kasipul and Suba sub county. The county covers an area of approximately 3,154.7 $\mathrm{km}^{2}$. Rachuonyo north and Rachuonyo south sub counties were randomly sampled to take part in the study. The residents of Homa bay County heavily depend on Lake Victoria as the main source of their livelihood as majority of the residents are either fishermen/women or fish mongers. The poverty rate in the county is at $44.1 \%$ and ranked 15 in the nation. Kisii County ranked number 34 with a poverty rate of $60.7 \%$, Kisumu County was ranked 21 with a poverty rate of $47.8 \%$, Migori

County was ranked 19 in the nation with a poverty rate of $46.7 \%$ and finally Nyamira County ranked 22 with a poverty 
rate of $48.1 \%$. The poverty rate was calculated by dividing the number of poor people in the county by the total population of the county Kenya County Fact Sheet [12]. This is further captured in Table 1 below.

Table 1. Poverty Rate in Homa bay County and the Neighboring Counties.

\begin{tabular}{lll}
\hline County & Poverty rate & Rank \\
\hline Homa bay & $44.1 \%$ & 15 \\
Migori & $46.7 \%$ & 19 \\
Kisumu & $47.8 \%$ & 21 \\
Kisii & $60.7 \%$ & 34 \\
Nyamira & $48.1 \%$ & 22 \\
\hline
\end{tabular}

Source: Kenya County Fact Sheets (2011)

In this study the family socioeconomic status was measured in terms of parental education, parental income and parent occupation. The study also focused on drug use, risky sexual behaviour and violence as some of the deviant behaviours exhibited by the students in Homa bay County.

\section{Research Methodology}

This study employed both quantitative and qualitative research methods and adopted a correlational study design. This design enabled the researcher to analyze interrelationship between the variables of the study (socioeconomic status and deviance), it also provided information concerning the degree and the direction of relationship between the two variables being studied Mertens [14].

\subsection{Target Population}

The target population consisted of form two students from the public and private secondary schools within Homa bay County. Homabay County has a total of eight sub counties with a population of 315 secondary schools and a target population of 20,160 form two students. $30 \%$ of the sub counties were randomly sampled. This translated to two sub counties with a population of 80 secondary schools and 5,120 form two students. According to Mertens [14], a sample size of between $10 \%$ and $30 \%$ adequately represents the target population. Further still,

Research Advisors (2006) opine that the recommended sample size for a population of 5,000, a confidence level of $95 \%$ and a margin of error (degree of accuracy) of $5 \%$ would be 357. Therefore, the representative sample of the students was 512 students from eight schools being $10 \%$ of the 5,120 form two students and 80 secondary schools respectively. This sampling matrix is further captured in Table 2.

The target population was 20, 160 students $(11,752$ boys and 8,408 girls). This population consisted of 27 girls' schools, 35 boys' schools and 253 mixed day and boarding secondary schools (Homabay County education officer, 2019). The sample size was determined using the following formula

$$
n=\frac{N}{1+N(e)^{2}}
$$

Where $\mathrm{n}=$ sample, $\mathrm{N}=$ the size of the population and $\mathrm{e}=$ the margin error.

Decide on the margin of error. According to Mertens [14], the margin of error is the statistical concept which expresses the difference between the population and the sample, although the sample is a sub set of the population. The confidence level for this study was at $95 \%(0.095)$ therefore the margin of error for this study was $5 \%$.

Sample proportion $\%=512 / 5120 \times 100=10.00 \%$

Girls' boarding schools $27 / 315 \times 100=8.57 \%$

Boys' boarding schools $35 / 315 \times 100=11.11 \%$

Mixed day and boarding schools 253/315 x $100=80.31 \%$

Girls' schools $=8.57 / 100 \times 512=44$ students

Boys' schools $=11.11 / 100 \times 512=57$ students

Mixed day and boarding $=80.31 / 100 \times 512=411$ students

Total $=512$ students

The principals, deputy principals and guidance and counseling HODs and parents' representatives were purposively picked from each school in the sample. These were picked as they had the relevant information with respect to the objectives of the study.

Table 2. Sampling Matrix.

\begin{tabular}{|c|c|c|c|c|}
\hline Sample unit & SamplingDesign & Target population & SampleSize & Percentage \\
\hline Schools & Random sampling & 80 & 8 & $10 \%$ \\
\hline Principals & Purposive sampling & 80 & 8 & $10 \%$ \\
\hline HOD G\&C & Purposive sampling & 80 & 8 & $10 \%$ \\
\hline Students & Random sampling & 5,120 & 512 & $10 \%$ \\
\hline PA & Purposive sampling & 80 & 8 & $10 \%$ \\
\hline Deputy & Purposive sampling & 80 & 8 & $10 \%$ \\
\hline
\end{tabular}

Source: Author's Data (2019)

\subsection{Research Instruments}

Primary data was obtained from students, teachers and parents through questionnaires, oral interviews and focus group discussions. In this study data was collected using socioeconomic status questionnaires for measuring family socioeconomic status, deviant behavior variety scale for measuring violence and drug use, Interest, Emotions and Relationships Scale for measuring irresponsible sexual behaviour, interview schedules, focus group discussions and 
document analysis.

Interview guides were used to gather information as they are flexible and enabled the researcher to collect larger amounts of information as compared to questionnaires. They ensured that adequate information was obtained from all the teachers and the parents' representatives. Interview appointments with the head teachers, deputies and heads of departments and all the parents' association representatives were made on phone for those who could not be reached physically.

For Parents, the interview guides were aimed at gathering the respondents' general information such as level of education, house hold income, their occupation, how they related with their children and how these contributed to the behavior of their children. The study adapted the interview guide for parents by Mwangi [17] with a few adjustments done to the instrument. Interview was conducted by the researcher in person at an agreed time and venue.

For teachers, the guide was aimed at gathering information about the students' SES, how this contributed to the behavior of the student and how the parents were attached to their students in terms of their SES. The guide that was used in this study was developed by the researcher and piloted to examine the appropriateness.

Document analysis is a qualitative data analysis technique which involves systematic procedure of reviewing or evaluating documents-both printed and electronic material Bowen [3]. It requires that data be scrutinized and interpreted in order to create meaning and to come up with an empirical knowledge. The documents which were analyzed included; class registers, dormitory/house registers and student files. These helped to provide background information as well as historical insights and consequently to get a better understanding of the deviant behaviours portrayed by the participants.

Focus group is a discussion aimed at igniting a conversation around a particular subject. It is more effective because in a group of peers members are more free and open and the diversity within the group enriches the quality and quantity of information collected Abawi [1]. In this study FGDs were conducted in eight forty-minute sessions for each group of ten participants in the schools that took part in the study.

\section{Results and Discussions}

The study achieved $100 \%$ questionnaire return rate in which all the questions were answered.

The distribution of respondents by their SES was in three categories as shown on table 3 below.

Table 3. Distribution of Respondents by their SES.

\begin{tabular}{lll}
\hline SES & N & Percentage \\
\hline Low SES & 382 & 74.6 \\
Middle SES & 102 & 20 \\
High SES & 28 & 5.4 \\
Total & 512 & 100 \\
\hline
\end{tabular}

\subsection{Family Socioeconomic Status}

To address the objective of the study, the null hypothesis 'There is no statistically significant relationship between family socioeconomic status and deviant behavior among secondary school students in Homabay County." was tested. A correlation analysis was conducted. The set scores on the family socioeconomic status were used as the independent variable while scores from deviant

behavior questionnaire were used as the explanatory variable (dependant variable). Responses on the family SES were as captured on table 4 below.

Table 4. Responses on Family Socioeconomic Status (SES).

\begin{tabular}{llll}
\hline Descriptive statistics & & Mean & Std. Deviation \\
\hline & N & 1.31 & .461 \\
\hline Finished some primary education or did not go to school & 512 & 1.18 & .382 \\
Finished lower secondary & 512 & 1.52 & .519 \\
Finished form 3 and four & 512 & .316 \\
Finished university or higher & 512 & 1.11 & .410 \\
Finished post secondary but not university & 512 & 1.21 & .768 \\
Has never worked outside the home for pay & 512 & 1.56 & .521 \\
Small business owner & 512 & 2.33 & .422 \\
Clerk & 512 & 2.18 & .303 \\
Service or sales worker & 512 & 2.08 & .203 \\
Skilled agricultural worker & 512 & 2.03 & .163 \\
Craft or trade worker & 512 & 2.02 & .107 \\
Plant or machine operator & 512 & 2.01 & .309 \\
General laborers & 512 & 2.10 & .076 \\
Professional & 512 & 2.00 & .107 \\
Technician or associate professional & 512 & 2.01 & .087 \\
\hline
\end{tabular}

Source: researcher's data 
Table 5. Students' Responses on Deviant Behaviour.

\begin{tabular}{|c|c|c|c|}
\hline & $\mathbf{N}$ & Mean & Std. Deviation \\
\hline I Have lied to Adults & 512 & 2.98 & 1.347 \\
\hline I have used cocaine or heroin & 512 & 1.96 & 1.016 \\
\hline I have fought an adult & 512 & 2.13 & 1.011 \\
\hline Used alcohol or bhang & 512 & 2.19 & 1.157 \\
\hline Skipped school for several days without parent's knowledge & 512 & 2.21 & 1.083 \\
\hline Sold drugs & 512 & 2.20 & 1.912 \\
\hline Carried a weapon to school (knife, pistol) & 512 & 2.10 & 1.093 \\
\hline Fought in class or in school & 512 & 2.36 & 1.092 \\
\hline Been to school or class after drinking alcohol & 512 & 2.11 & 1.068 \\
\hline Planned to destroy school property & 512 & 2.12 & 1.096 \\
\hline Planned to/ burn school building & 512 & 2.13 & 1.075 \\
\hline \multirow[t]{2}{*}{ Carried alcohol or any other drug to school } & 512 & 2.02 & 1.047 \\
\hline & 512 & & \\
\hline
\end{tabular}

Table 6. Students' Responses on Irresponsible Sexual Behaviour.

\begin{tabular}{|c|c|c|c|}
\hline \multicolumn{4}{|l|}{ Descriptive Statistics } \\
\hline & $\mathbf{N}$ & Mean & Std. Deviation \\
\hline I have already had sex with boy or a girl & 512 & 2.90 & 1.277 \\
\hline I have a child at home & 512 & 2.05 & 1.111 \\
\hline I plan to wait to get someone I love before having sex & 512 & 3.34 & 1.214 \\
\hline I find it difficult to say no to sexual advances from the opposite sex & 512 & 2.85 & 1.340 \\
\hline I would not wish to have a sexual relationship before finishing school & 512 & 3.48 & 1.238 \\
\hline I plan to have sex as soon as the opportunity arises & 512 & 2.47 & 1.293 \\
\hline
\end{tabular}

\subsection{Quantitative Data Analysis}

The correlation analysis of the data collected produced the results captured on table 7 below.

Table 7. Correlation between Family Socioeconomic Status and Deviant Behaviour.

\begin{tabular}{llll}
\hline & & Socio-economic status & Deviant Behaviour \\
\hline & Pearson Correlation & 1 & $-.644^{* *}$ \\
Socio-economic status & Sig. (2-tailed) & & .000 \\
& $\mathrm{~N}$ & 512 & 512 \\
& Pearson Correlation & $-.644^{* *}$ & 1 \\
Deviant Behaviour & Sig. (2-tailed) & .000 & 512 \\
& $\mathrm{~N}$ & 512 \\
\hline
\end{tabular}

**. Correlation is significant at the 0.05 level (2-tailed).

The Pearson Product-Moment correlation coefficient computed implies a strong significant negative correlation between family socioeconomic status and deviant behavior among secondary school students in Homabay County, with $(\mathrm{r}=-0.644, \mathrm{p}<0.0)$ These findings are reminiscent to those of Mohnsen, Mehr and Rohmati [16] who revealed that adolescents from families that have higher levels of SES were more active and participated in sports than others. Chu [5] revealed that upper middle class students performed better than those from lower middle class. Similarly, Ruqaya, Ghulam and Asif [26] reported that low socioeconomic statuses are important predictors of aggression among the youth. Alicea [2] noted that students from higher SES group reported higher adaptability. Patrick, Shoeni and Schulenberg [25] revealed that smoking in young adulthood was associated with lower childhood family SES. The findings of this study also corroborated with those of Kori [13] whose findings averred that family context variables contributed significantly to risky sexual behavior.

Dekeke and Sandy [6] also reported that level of parental education plays an important role in youths' initiation to risky sexual behavior. Of the same opinion are Dintwa and Kakanya [6] who revealed that economic status influences risky sexual behavior and commercial sex. Ekpo and Ajake [8] also reported that family SES and educational level of parents significantly influence students' delinquency. In addition to this, Ntaganira et al [19] revealed that risky sexual behavior among the $\mathrm{YHH}$ was highly related to their SES. Olugbode [20] also opined that students' academic performance and social adjustment in school are largely affected by the social problems around them and family income is among these factors. Others who also agree with the findings of this study are Uyang, Festus and Bassey [30] who found that SES of the youth is a significant cause of youth involvement in criminal activities. Omboto et al [21] also reported that more than $70 \%$ of the imprisoned youths 
come from poor families. Similarly, Kasundu et al [11] averred that economic factors are of great significance as far as drug abuse is concerned. Omollo [22] also reported that SES factors highly influence the retention of students in secondary schools. Finally, Ooyi [23] revealed that youths from high socioeconomic backgrounds participate more in HIV/AIDS prevention forums.

\subsection{Qualitative Data Analysis}

In addition to quantitative results, qualitative data revealed varied views concerning the study objective. Majority of the respondents were characterized as poor. This is illustrated by the following responses "My father works as a night watchman in our school but he is not paid because the money goes to my school fees, while my mother is a fish monger at the market." Others also reported that both parents are peasant farmers. Those who fell in this category indicated that their parents earn less than ksh.10,000/. Those who were categorized as middle class earned ksh. 50, 000/ per annum while very few were categorized as rich. These indicated that their parents were both high school teachers, one student reported that his father is an engineer who owned his own construction company while others reported that their parents owned businesses.

When the students were asked whether their parents took too long at work and whether this contributed to their behaviour, their responses differed as shown in the table 8 below

Table 8. Time Spent by Parents Away from Home.

\begin{tabular}{lllll}
\hline Parent spends more time at workthan at home & F & \% & CONT & \% \\
\hline Never & 22 & 27 & 40 \\
Sometimes & 42 & 53 & 14 \\
Always & 16 & 20 & 26 \\
Total & 80 & 100 & 33 & 80 \\
\hline
\end{tabular}

Source: Researchers' Data (2019)

From the above responses when students were asked whether their parents spent more time at work than at home, $53 \%$ responded that they sometimes do. Another 20\% reported that they always do while the rest $27 \%$ said their parents never spend more time at work than at home. Whether the time their parents spend at home contributes to their behavior $50 \%$ denied while the other $50 \%$ agreed $(17 \%$ sometimes while $33 \%$ always). These responses imply that there is a relationship between parental occupation and deviant behavior as the respondents agreed that the time their parents spend at work contribute to their behaviour. According to the interview, majority of the students spend most of their time after school at home alone because parents come home late while some parents live away from home.

The study also sought to find out whether their parents' income contributed to their behavior. The respondents presented varied responses with majority suggesting that they behave the way they do either because their parents are unable to provide them with the basic needs or because the parents are not there to direct them as implied in the following statements;

"If my mother had enough money I know I would not be in a day school and for sure there are some friends I would not be keeping. I know she would buy me good clothes and provide all that I need" (FGD)

The above response presents a student who wishes to lead a better life and admits that there are friends whom she knows are not good but she cannot avoid them because these friends sustain her.

"If my father had money I know we would not be living in a slum, he would be supporting me in my education and I know he would spend more time at home instead of drinking alcohol." (FGD)

When parents were asked whether their socioeconomic statuses contributed to the behavior of their children, most of them agreed that it does both positively and negatively. Most of the parents whose children were in day school reported that if they were employed they would take their children to better schools because they felt that day schooling had a bad influence on their behavior. [Parent 5]. One parent felt that because of the nature of his job he never gets enough time to be with his children and even to visit their school and he believes that this contributed to their laxity in their academics. [Parent 8]. Furthermore some also appreciated their employment because they believe that they were only able to pay school fees on time because of the employment otherwise their children would be out of school.

On whether SES related to behavior, teachers agreed that it does. However their opinion was divided right in the middle on whether the contribution was negative or positive. There were those teachers who believed that children from rich families have a lot of money which they use to buy drugs and lure others into sexual relationships. Other teachers reported that poverty motivated students to work extra hard and to focus only on education in order to deliver their families from poverty. On the contrary, other teachers reported that sometimes the poor conditions at home are too harsh to favor learning and so these students become emotionally vulnerable and are easily provoked to violence and bunking school.

From the findings of document analysis, most students who are deviant come from poor families. For example, Jane (pseudonym) comes from a two parent home, all parents are not employed (from a lower SES). She is asleep most of the times in class, has exhibited disruptive behavior in class and was once found

in possession of a pair of scissors which she intended to use against a boyfriend who had dumped her. 
Further still, it was revealed that some students have been labeled as deviants and have never brought their parents to school even when they are sent home to call parents for example, job (pseudonym) fights in school and when he is sent home to call his parents he threatens to leave school because the parents are not willing to come to school and so the teachers call him back.

\section{Conclusion}

In conclusion, the study found a very strong significant, negative correlation between family SES and deviant behaviour among secondary school students in Homa bay County. Students from poor families face a lot of social strains which expose them to deviance. Poor parents are also unable to spend quality time with their children since most of the time they are out working in order to fend for their children. Some of the children from poor families are also subjected to child labour hence denying them a chance to spend quality time with their parents. The study recommends effective poverty eradication measures within Homa bay County. The study also recommends that the county government of Homabay should introduce free and active adult education in the County and build such centers within the county. This would ensure lifelong learning for the parents and even the youths who drop out of school to go and get married. In the long run, adult education would enable the parents to expand their knowledge and also to increase their income thus increasing their SES and consequently a positive behavior change among the adolescents.

\section{References}

[1] Abawi, K. (2013). Data collection instruments (questionnaire and interview). Paper presented at: Geneva Workshop.

[2] Alicea J. D. (2012). Examining Gender and Socioeconomic Status on the Emotional Intelligence of Early Adolescents. PCOM Psychology Dissertations. Paper 211.

[3] Bowen G. (2009). Document Analysis as a Qualitative Research Method. Qualitative Research Journal. Vol. 9, No. 2, pp. 27-40 doi; 10.3316/QRJ0902027

[4] Changalawa, C. N., Ndurumo, M. M., Barasa, L. P., \& Poipoi, W. M. (2012). The Relationship between Parenting Styles and Alcohol Abuse among College Students in Kenya. Greener Journal of Educational Research. Vol. 2 (2): 013-020 ISSN 2276-7789.

[5] Chu, Y. W. (2014). The Influence of Socioeconomic Status and Parenting Style on the Academic Achievement in English of Junior High School Students in Taiwan.

[6] Dekeke, G. D., \&Sandy, P. T. (2014). Factors Influencing Sexual Risk Behaviors among Senior Secondary School Students (Youths). International Journal of Scientific and Research Publications. Vol. 4, Issue 8 ISSN 2250-3153.

[7] Dintwa, K. F. (2012). Economic Status, Education and Risky Sexual Behavior for Urban Botswana Women. Journal of International Women's Studies. 13 (3), 153-170. http://vc.bridgew.edu/jiws/vol13/iss3/11.

[8] Ekpo, T. E. \& Ajake, U. E. (2013). Family Socio Economic Status and Delinquency Among Senior Secondary School Students in Calabar South, Cross river state, Nigeria.

[9] Giddens A. \& Sutton, W. P. (2017). Essential Concepts in Sociology, Polity Press: Cambridge, pp 223. ISBN 978-0-74569668-3.

[10] Harrison, M. K. (2013). Community Violence Exposure among Underprivileged 20. Adolescents; What are the Buffering Effects of Family Qualities on Negative Outcomes.

[11] Kasundu, B., Mutiso, M. M., Chebet, S. P., Chesire, M. \& Mwirigi, W. P. (2012). Factor Contributing to Drug Abuse among the Youth in Kenya: A Case of Bamburi Location. Elixir International Journal of Social Sciences. Vol. 46: 82598267.

[12] Kenya County Fact Sheet (2011). Commission on Revenue Allocation. www.crakenya.org

[13] Kori, M. D. (2015). Predicting Risky Sexual Behavior: Role of Family Context Factors and Socio-economic Status. Theses and Dissertations. Paper 481 http://:r.library.illinoisstate.edu/etd.

[14] Mertens, D. M. (2010). Research and Evaluation in Education and Psychology: Integrating Diversity with Quantitative, Qualitative and Mixed Methods. Journal of Mixed Methods Research 4 (1): 3-5.

[15] Merton, K. Robert (1940). Bureaucratic Structure and Personality. Social Forces, vol. 18, Issue 4: 560-568.

[16] Mohsen, M. N., Mehr, A. H. N., \& Mohammad, M. R. (2012). Relationship between Socio-economic Status of Family and Adolescents Students Sport Participation. Annals of biological $\begin{array}{llll}\text { research } & 3 & \text { (8): } & 4012-4016\end{array}$ (http://scholarsresearchlibraryCom/archive.html

[17] Mwangi, M. W. (2016). Influence of Parents' Socioeconomic Status on Their Participation in Children's Preschool Education in Kayole, Nairobi. http://irlibrary.kuac.ke/bitstream/handle/123456789/17577.

[18] Nezhad H. M, Rahmati, M. M., \& Nezhad, M. M. (2012). Relationship between Social -Economic status of Family and Adolescents student Sport Participation. Annals of Biology Research, 2012, 3 (8): 4012-4016 ISSN 0976-1233 www.scholarsresearchlibrary.com

[19] Ntaganira, J., Hass, J. L., Hosner S., Brown, L. \& Mock, B. N. (2012). Sexual Risk Behaviors among Youth Heads of Households in Gikongoro, South Province of Rwanda. BMC Public Health. https://doi.org/10.1186/1471-2458-12-225

[20] Olugbode, A. (2013). Effects of Social Problems on the Academic Performance and Social Adjustments in Shomolu Education District II of Lagos State.

[21] Omboto, J. O., Ondiek, G. O., Odera, O. \& Ayugi, M. E. (2013). Factors Influencing Youth Crime and Juvenile Delinquency. International Journal of Research in Social Sciences. Vol. 1 N. 2 ISSN 2307-227.

[22] Omollo, A. E. (2017). Influence of Peer Pressure on Secondary School Students Drop out inRongo Sub County, Migori County, Kenya. Journal of Education and Practice. ISSN 2222-1735 (paper) ISSN 2222-288X (online) Vol. 8, No. 9. 
[23] Ooyi, G. (2016). Determinants of Youth Participation in Prevention of HIV and AIDs in Secondary Schools in Suba District Homabay County, Kenya. Research Gate Doi: 10.13140/RG:2.1.3959.1280

[24] Parks, A. B. (2013). The Effects of Family Structure on Family Delinquency. Electronic Theses and Dissertations. paper 2279. http://dc.etsu.edu/etd/2279

[25] Patrick, M. E., Whiteman, P., Shoeni, R. F. \& Schulenberg, J. E. (2012). The Association between Family Socioeconomic Status during Childhood and Parental Education with Smoking Alcohol se and Marijuana Use during Young Adulthood. Jstud Alcohol Drugs 73 (5): 772-82.

[26] Ruqaya I., Ghulam Y. \&Asif, Y. (2010). Sociological Study of the Factors Affecting the Aggressive Behaviour among Youth. Pakistan Journal of Social Sciences (PJSS). Vol. 30 No. 1: 99108.
[27] Tadesse, G. B., Mitikie, M., Yemane, B., Amenu, W., \& Tesfaye, C. (2016). Determinants of Risky Sexual Behaviour among Preparatory School Students in Gurage Zone, SNNPR, Ethiopia (A Cross-Sectional School Based Study), Science Journal of Public Health. Vol. 4, No. 4, 2016: 330-341. doi: 10.11648/j.sjph.20160404.2.

[28] The National Crime Research Centre (2016). Rapid Assessment of Arsons in Secondary Schools in Kenya. www.crimeresearch.go.ke

[29] Uyang, F. A., Festus, N. \& Bassey, G. E. (2016). Socio Economic Status of Youth an Involvement in Criminal Activities in Calabar Metropolis of Cross River State, Nigeria. International Journal of Humanities Social Sciences and Education (Vol. 3 Issue 1: 79-83 ISSN 2349-0381. 